Article

\title{
Catalytic Hydrodeoxygenation of Fast Pyrolysis Bio-Oil from Saccharina japonica Alga for Bio-Oil Upgrading
}

\author{
Hoang Vu Ly ${ }^{1,2}$, Jinsoo Kim ${ }^{2, *}$, Hyun Tae Hwang ${ }^{3}$, Jae Hyung Choi ${ }^{4}$, Hee Chul Woo ${ }^{4}$ \\ and Seung-Soo Kim ${ }^{1, *}$ \\ 1 Department of Chemical Engineering, Kangwon National University, Samcheok, Gangwon-do 25913, Korea; \\ lyhoangvu87@gmail.com \\ 2 Department of Chemical Engineering, Kyung Hee University, Giheung-gu, Yongin, \\ Gyeonggi-do 17104, Korea \\ 3 Department of Chemical and Materials Engineering, University of Kentucky, 4810 Alben Barkley Drive, \\ Paducah, KY 42002, USA; hyun-tae.hwang@uky.edu \\ 4 Department of Chemical Engineering, Pukyong National University, 365 Sinseon-ro, Nam-gu, \\ Busan 48513, Korea; jhchoe@pknu.ac.kr (J.H.C.); woohc@pknu.ac.kr (H.C.W.) \\ * Correspondence: jkim21@khu.ac.kr (J.K.); sskim2008@kangwon.ac.kr (S.-S.K.); Tel.: +82-31-201-2492 (J.K.); \\ $+82-33-570-6544$ (S.-S.K.)
}

Received: 17 October 2019; Accepted: 3 December 2019; Published: 8 December 2019

\begin{abstract}
Biomass conversion via pyrolysis has been regarded as a promising solution for bio-oil production. Compared to fossil fuels, however, the pyrolysis bio-oils from biomass are corrosive and unstable due to relatively high oxygen content. Thus, an upgrading of bio-oil is required to reduce O component while improving stability in order to use it directly as fuel sources or in industrial processes for synthesizing chemicals. The catalytic hydrodeoxygenation (HDO) is considered as one of the promising methods for upgrading pyrolysis bio-oil. In this research, the HDO was studied for various catalysts (HZSM-5, metal, and metal-phosphide catalysts) to improve the quality of bio-oil produced by fast pyrolysis of Saccharina japonica (SJ) in a fluidized-bed reactor. The HDO processing was carried out in an autoclave at $350{ }^{\circ} \mathrm{C}$ and different initial pressures $(3,6$, and $15 \mathrm{bar})$. During HDO, the oxygen species in the bio-oil was removed primarily via formation of $\mathrm{CO}_{2}$ and $\mathrm{H}_{2} \mathrm{O}$. Among the gases produced through $\mathrm{HDO}, \mathrm{CO}_{2}$ was observed to be most abundant. The $\mathrm{C} / \mathrm{O}$ ratio of produced bio-oil increased when $\mathrm{CoMoP} / \gamma-\mathrm{Al}_{2} \mathrm{O}_{3}, \mathrm{Co} / \gamma-\mathrm{Al}_{2} \mathrm{O}_{3}, \mathrm{Fe} / \gamma-\mathrm{Al}_{2} \mathrm{O}_{3}$, or HZSM- 5 was used. The $\mathrm{Co} / \gamma-\mathrm{Al}_{2} \mathrm{O}_{3}$ resulted in higher $\mathrm{HDO}$ performance than other catalysts. The bio-oil upgraded with $\mathrm{Co} / \gamma-\mathrm{Al}_{2} \mathrm{O}_{3}$ showed high HHV (34.41 MJ/kg). With the use of catalysts, the kerosene-diesel fraction (carbon number $\mathrm{C}_{12}-\mathrm{C}_{14}$ ) was increased from 36.17 to $38.62-48.92 \mathrm{wt} . \%$.
\end{abstract}

Keywords: S. japonica alga; fast pyrolysis; upgrading bio-oil; catalytic hydrodeoxygenation; autoclave

\section{Introduction}

Biomass has attracted considerable attention as an alternative energy resource to replace nonrenewable fossil fuels. Biomass feedstocks including agricultural residues [1], forestry waste [2,3], plastic [4], aquatic plant [5,6], and sewage sludge [7], are inexpensive and can be further utilized to produce a variety of valuable chemicals and biomaterials as well as energy $[5,8]$. Among the various resources for renewable energy, macroalgae offers great promise as feedstock for biofuel production due to its higher growth rate even in wastewater and seawater, higher yield, and shorter harvesting cycle, compared to terrestrial biomass. Thermal conversion via pyrolysis has received a lot of attention as a promising technique to produce biofuel from macroalgae. Kim et al. $[9,10]$ investigated the pyrolysis 
characteristics and kinetics of Saccharina japonica (SJ) alga and Sargassum sp. and found that the bio-oil produced at optimum conditions showed a higher heating value (HHV) of $31.9 \mathrm{MJ} / \mathrm{kg}$ and an $\mathrm{O} / \mathrm{C}$ molar ratio of 0.16. Ly et al. [5] produced bio-oils with HHVs in the range of $24.75-28.72 \mathrm{MJ} / \mathrm{kg}$ by fast pyrolysis of SJ. By pretreating Enteromorpha clathrata alga with diluted $\mathrm{HCl}$, Cao et al. [11] enhanced the yield of the bio-oil by $9.6 \%$.

However, pyrolytic bio-oils contain a lot of oxygen-containing compounds, leading to a decrease in the bio-oil quality [3,12]. For this reason, in order for bio-oil to be directly used as transportation or boiler fuel, an upgrading process to lower the oxygen content in bio-oil is required. Catalytic pyrolysis is known as one of the most promising methods for upgrading bio-oil. In the presence of catalyst, the $\mathrm{O}$-species in the bio-oils are released as forms of $\mathrm{CO}_{2}, \mathrm{CO}$, and/or $\mathrm{H}_{2} \mathrm{O}$, or converted directly to hydrocarbons at atmospheric pressure, resulting in improvement of bio-oil quality [12]. Ly et al. [3] also studied the catalytic pyrolysis of tulip tree (Liriodendron) in a fluidized-bed reactor with dolomite catalyst. They reported that oxygen content in the bio-oil was mostly removed as water via dehydration. In addition, gaseous products released together were found to have a high $\mathrm{H}_{2} / \mathrm{CO}$ ratio. The effect of HZSM- 5 as a catalyst on the composition of pyrolyzed bio-oil from microalgae with high contents of nitrogen and oxygen was investigated by Lorenzetti et al. [13]. They found that the upgraded bio-oil contained high amounts of aromatic hydrocarbon, while contents of oxygen and nitrogen were relatively small. The catalytic deoxygenation over hydrotreating, known as catalytic hydrodeoxygenation (HDO), has been accepted as a potential method for efficient removal of oxygen in bio-oil. Due to high catalytic activity along with inexpensive material cost, alumina, zeolites, silica, and activated carbon have been commonly employed as supports for various HDO catalysts. Selecting 2-furyl methyl ketone (FMK) as a model compound, Ly et al. [14] obtained relatively high conversion $(>83 \%)$ of FMK with Ni-based catalysts $\left(\mathrm{Ni} / \gamma-\mathrm{Al}_{2} \mathrm{O}_{3}\right)$. They also found that HDO was enhanced by addition of phosphorous, which influences the structural properties of active phase [14]. In particular, transition metal phosphide catalysts have been reported to show excellent activities on HDO [14-16]. The HDO processes with supported-metallic catalysts were investigated to upgrade pyrolytic bio-oils $[17,18]$. Cheng et al. [18] studied the HDO of bio-oil from pine sawdust with $\mathrm{Fe}-\mathrm{Co} / \mathrm{SiO}_{2}$ catalysts and found that the bimetallic $\mathrm{Fe}-\mathrm{Co} / \mathrm{SiO}_{2}$ catalysts $(\mathrm{Fe} / \mathrm{Co}$ ratio of $1: 1)$ showed better performance, as compared to monometallic catalysts (e.g., $\mathrm{Fe} / \mathrm{SiO}_{2}$ and $\mathrm{Co} / \mathrm{SiO}_{2}$ ).

In the present study, different catalysts including HZSM-5, metal (Fe and $\mathrm{Co}$ ), and metal phosphide $\left(\mathrm{Fe}_{2} \mathrm{P}, \mathrm{CoP}\right.$, and $\left.\mathrm{CoMoP}\right)$ supported on $\gamma-\mathrm{Al}_{2} \mathrm{O}_{3}$ were examined for upgrading bio-oil obtained by pyrolysis of SJ. In addition, the feasibility of applying inexpensive catalysts to HDO processes was investigated, by testing in an autoclave at $350{ }^{\circ} \mathrm{C}$ and pressure varying from 3 to 15 bar. Finally, the compositions of the products and the catalysts were systematically analyzed using various techniques.

\section{Results and Discussion}

\subsection{Catalysts and Sample Characterization}

The X-ray diffractogram of catalysts was reported in Figure 1 . The peaks at $2 \theta=31.93^{\circ}, 37.67^{\circ}$, $45.78^{\circ}$, and $66.35^{\circ}$ were associated with $\gamma-\mathrm{Al}_{2} \mathrm{O}_{3}$ support. Two main peaks for HZSM- 5 were displayed at $22.86^{\circ}$ and $23.89^{\circ}$ [19]. The peaks related to $\mathrm{Fe}$ phase in $10 \mathrm{wt} . \% \mathrm{Fe} / \gamma-\mathrm{Al}_{2} \mathrm{O}_{3}$ catalyst were observed at $2 \theta=44.64^{\circ}$ and $65.05^{\circ}$. The peaks of $\mathrm{Fe}_{3} \mathrm{O}_{4}$ appeared at $2 \theta$ values of $18.77^{\circ}, 35.87^{\circ}, 57.64^{\circ}$, and $62.91^{\circ}$. This result indicates that the $\mathrm{Fe}_{2} \mathrm{O}_{3}$ phase was transformed into $\mathrm{Fe}_{3} \mathrm{O}_{4}$ phase and further to Fe metallic phase. The peak corresponding to $\mathrm{Fe}_{2} \mathrm{P}$ could be observed at $38.4^{\circ}$. In the XRD patterns for Co-containing catalysts, the peaks of CoP phase appeared at $2 \theta=31,62^{\circ}, 35.23^{\circ}, 40.12^{\circ}, 48.19^{\circ}$, and $56.69^{\circ}, \mathrm{Co}$ at $42.39^{\circ}, 51.24^{\circ}, 54.01^{\circ}$, and $75.45^{\circ}$, and the peaks of spinel $\mathrm{Co}_{3} \mathrm{O}_{4}$ at $31.89^{\circ}, 37.02^{\circ}$, $59.64^{\circ}$, and $65.86^{\circ}$. The peaks $25.94^{\circ}, 36.98^{\circ}$, and $69.88^{\circ}$ were attributed to $\mathrm{MoO}_{2}$, while the signals at $28.03^{\circ}, 32.28^{\circ}$, and $43.20^{\circ}$ for the spinel MoP. These XRD results were consistent with those reported in previous studies [14-16]. 


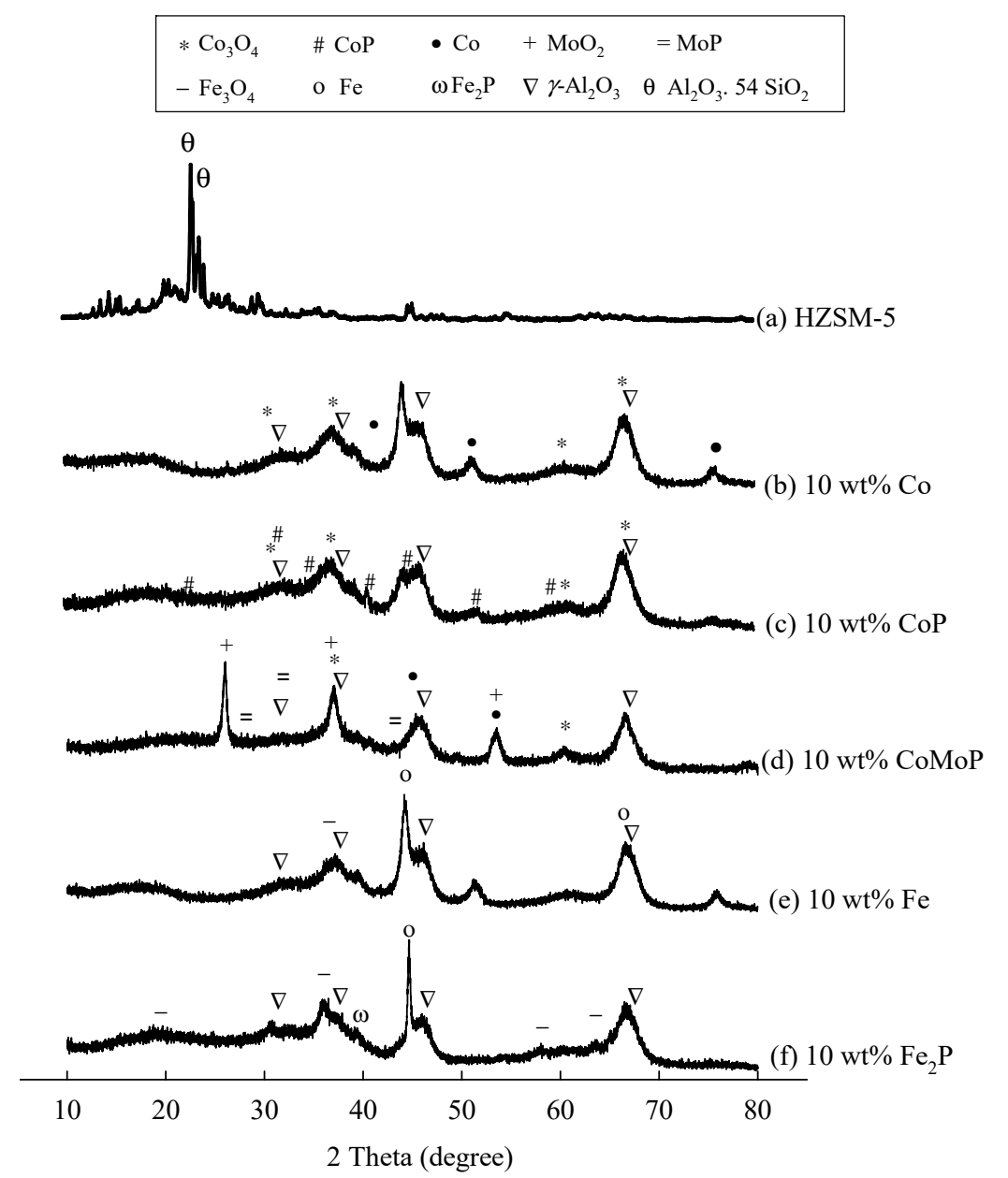

Figure 1. XRD patterns of (a) HZSM-5 and $\gamma-\mathrm{Al}_{2} \mathrm{O}_{3}$-supported catalyst with (b) $10 \mathrm{wt} . \% \mathrm{Co}$, (c) $10 \mathrm{wt} . \%$ $\mathrm{CoP},(\mathbf{d}) 10$ wt. $\%$ CoMoP, (e) 10 wt. $\%$ Fe, and (f) 10 wt. $\% \mathrm{Fe}_{2} \mathrm{P}$.

The BET surface area $\left(\mathrm{S}_{\mathrm{BET}}\right)$, the pore volume, and the average pore size of HZSM- 5 were determined to be $132.49 \mathrm{~m}^{2} / \mathrm{g}, 0.14 \mathrm{~cm}^{3} / \mathrm{g}$, and $6.70 \mathrm{~nm}$, respectively. As presented in Table 1, the prepared catalysts $\left(\mathrm{Co}, \mathrm{CoP}, \mathrm{Fe}, \mathrm{Fe}_{2} \mathrm{P}\right.$, and $\mathrm{CoMoP}$ on $\left.\gamma-\mathrm{Al}_{2} \mathrm{O}_{3}\right)$ showed the textual properties with specific surface area ranging from 184.82 to $211.08 \mathrm{~m}^{2} / \mathrm{g}$, the pore volume $0.40-0.43 \mathrm{~cm}^{3} / \mathrm{g}$, and the average pore size $7.05-8.09 \mathrm{~nm}$. As reported in our prior study [9], the moisture and ash contents of SJ sample were $6.90 \mathrm{wt} . \%$ and $20.21 \mathrm{wt} . \%$, respectively. Table 2 shows the characteristics of SJ and SJO. As shown in Table 2, the HHV of SJO was determined to be $26.10 \mathrm{MJ} / \mathrm{kg}$, which was higher than that of woody biomass such as tulip tree (18.87 MJ/kg) [3] and Pinyon pine (18.94 MJ/kg) [2].

Table 1. Pore structure data of different catalysts.

\begin{tabular}{ccccc}
\hline Catalyst & $\begin{array}{c}\text { Calcination } \\
\text { Temperature }\left({ }^{\circ} \mathbf{C}\right)\end{array}$ & $\begin{array}{c}\text { Surface Area } \\
\left(\mathbf{m}^{\mathbf{2}} / \mathbf{g}\right)\end{array}$ & $\begin{array}{c}\text { Pore Volume } \\
\left(\mathbf{c m}^{\mathbf{3}} / \mathbf{g}\right)\end{array}$ & $\begin{array}{c}\text { Average Pore Size } \\
(\mathbf{n m})\end{array}$ \\
\hline $\mathrm{HZSM}-5$ & 550 & 132.49 & 0.04 & 6.7 \\
10 wt.\% $\mathrm{Co} / \gamma-\mathrm{Al}_{2} \mathrm{O}_{3}$ & 600 & 184.82 & 0.40 & 7.79 \\
10 wt. $\% \mathrm{Fe} / \gamma-\mathrm{Al}_{2} \mathrm{O}_{3}$ & 600 & 203.71 & 0.43 & 8.09 \\
10 wt. $\% \mathrm{CoP} / \gamma-\mathrm{Al}_{2} \mathrm{O}_{3}$ & 600 & 209.87 & 0.43 & 7.05 \\
10 wt. $\% \mathrm{Fe} 2 \mathrm{P} / \gamma-\mathrm{Al}_{2} \mathrm{O}_{3}$ & 600 & 204.72 & 0.41 & 7.67 \\
10 wt. $\% \mathrm{CoMoP} / \gamma-\mathrm{Al}_{2} \mathrm{O}_{3}$ & 600 & 211.08 & 0.42 & 7.56 \\
\hline
\end{tabular}


Table 2. Characteristics of Saccharina japonica (SJ) and raw Saccharina japonica bio-oil (SJO).

\begin{tabular}{|c|c|c|c|c|c|c|c|c|c|}
\hline \multirow{2}{*}{$\begin{array}{c}\text { Proximate } \\
\text { Analysis (wt.\%) }\end{array}$} & \multirow{2}{*}{ Moisture $^{a}$} & \multirow{2}{*}{$\operatorname{Ash}^{b}$} & \multirow{2}{*}{$\begin{array}{l}\text { Volatile } \\
\text { Matter }^{\mathrm{c}}\end{array}$} & \multirow{2}{*}{$\begin{array}{c}\text { Fixed } \\
\text { Carbon }\end{array}$} & \multicolumn{4}{|c|}{ Elemental Analysis ${ }^{\mathrm{d}}$ (wt.\%) } & \multirow{2}{*}{$\begin{array}{l}\text { HHV } \\
(\mathrm{MJ} / \mathrm{kg})\end{array}$} \\
\hline & & & & & C & $\mathbf{H}$ & $\mathbf{N}$ & $\mathrm{O}^{\mathrm{e}}$ & \\
\hline S.J [9] & 6.90 & 20.21 & 68.79 & 4.10 & 32.89 & 6.17 & 0.93 & 60.01 & 12.11 \\
\hline Raw SJO & 2.14 & - & - & - & 61.96 & 8.02 & 2.21 & 27.81 & 27.45 \\
\hline
\end{tabular}

${ }^{a}$ ASTM E1756, Standard test method for the determination of the total solids of biomass. ${ }^{b}$ ASTM E1755, Standard test method for determination of ash content of biomass. ${ }^{\mathrm{c}}$ Calculating based on sample after drying. ${ }^{\mathrm{d}}$ On dry, ash free basis (for biomass material). ${ }^{\text {e }}$ By difference.

\subsection{Thermogravimetric Analysis of Biomass Samples}

The thermogravimetric analysis (TGA) combined with differential thermogravimetric analysis (DTG) is a high-precision technique to understand the characteristic of thermal decomposition of solid materials. The TGA enables to monitor the degree of conversion with temperature, while the differential rate of conversion (dX/dt) vs. temperature is expressed by DTG. Both TGA and DTG curves for original SJ and $\mathrm{SJO}$ at a heating rate of $20^{\circ} \mathrm{C} / \mathrm{min}$ are illustrated in Figure 2. Starting at $-40{ }^{\circ} \mathrm{C}$, most of $\mathrm{SJO}$ conversion was obtained below $500{ }^{\circ} \mathrm{C}$, which is ascribed to the decomposition of organic components in the SJO. According to the simulated distillation by TGA $[3,12,20]$, this decomposition temperature range $\left(40-500^{\circ} \mathrm{C}\right)$ corresponded to the boiling point of the organic products with carbon numbers from $\mathrm{C}_{5}$ to $\mathrm{C}_{38}$. It is also noteworthy that $80 \%$ of $\mathrm{SJO}$ was recovered within $350{ }^{\circ} \mathrm{C}$, and the maximum differential rate of conversion was observed at $200.43{ }^{\circ} \mathrm{C}$ in the DTG curve (b).
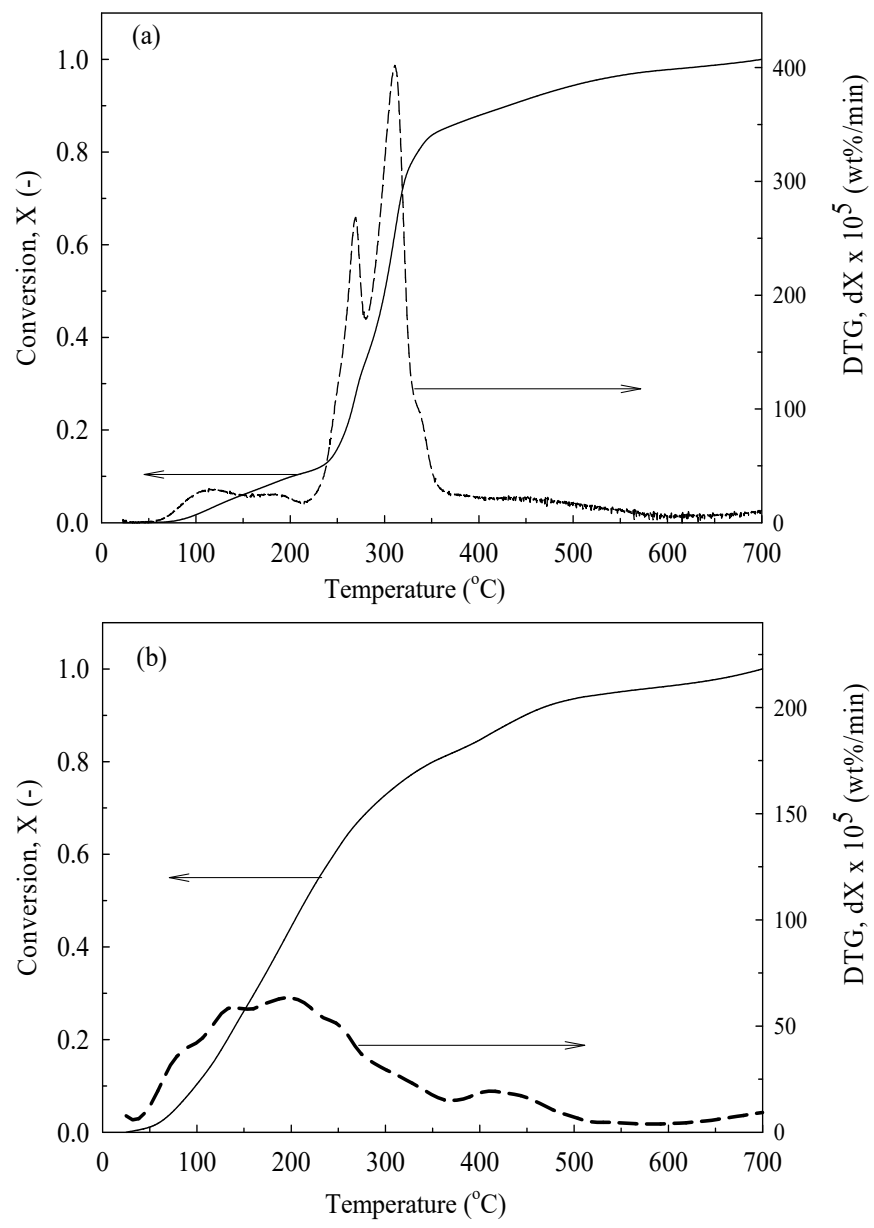

Figure 2. TGA and differential thermogravimetric analysis (DTG) of weight loss curves at a heating rate of $20^{\circ} \mathrm{C} / \mathrm{min}$ : (a) Saccharina japonica (SJ) macroalgae and (b) Saccharina japonica bio-oil (SJO). 


\subsection{Effect of Reaction Conditions on Product Distribution}

The effect of initial pressure on the HDO of SJO was investigated. With increasing reactor pressure, the gas yield decreased, while the liquid yield increased. It is likely because increased pressure results in the suppression of volatiles. The moisture content in the oil decreased with increasing reaction pressure, whereas the content of organic matter increased. The HHV of the bio-oil was in the range of 33.09-33.99 MJ/kg, which was little influenced by the pressure. As compared to raw bio-oil, however, the HHV of the bio-oil upgraded by HDO increased because oxygen species are reduced via dehydration, decarboxylation, and decarbonylation. The HHV of the upgraded bio-oils was higher than that of pyrolysis bio-oils from biomass such as tulip tree $(24.37 \mathrm{MJ} / \mathrm{kg})$ [3] and S. japonica $(26.1-28.27 \mathrm{MJ} / \mathrm{kg})[9]$.

The effect of catalysts on the HDO of SJO was also investigated for HZSM- 5 and various catalysts with $10 \mathrm{wt} . \%$ metal loading at $350^{\circ} \mathrm{C}$ and the initial pressure of 15 bar. As shown in Table 3, the product distributions were different for the catalysts tested, which were likely due to different reaction pathways. When HDO of SJO was conducted without catalyst, the liquid yield decreased, whereas the gas yield increased, compared to catalytic HDO. The maximum liquid yield was $78.60 \mathrm{wt} . \%$, observed for HZSM-5. The highest value of gas yield was $15.21 \mathrm{wt} . \%$, achieved by $\mathrm{HDO}$ using $\mathrm{Co} / \mathrm{Al}_{2} \mathrm{O}_{3}$. As a result, the addition of metal on $\gamma-\mathrm{Al}_{2} \mathrm{O}_{3}$ support $\left(\mathrm{Co} / \gamma-\mathrm{Al}_{2} \mathrm{O}_{3}\right.$ and $\left.\mathrm{Fe} / \gamma-\mathrm{Al}_{2} \mathrm{O}_{3}\right)$ decreased the liquid and char yields, while the gas yield was increased. This might be due to the catalytic cracking reaction, which produced lower molecular weight compounds and non-condensable gas, followed by a series of deoxygenation reactions [12]. When HZSM-5 was applied, the liquid yield was decreased, but the char yield was increased, compared to HDO in the absence of the catalyst. An increase in the char yield might be due to the formation of coke on the surface of HZSM-5 by repolymerization and aromatization of aromatic compounds in liquid products [12].

When phosphorus was added into the metal catalysts, however, significant changes in the solid yield were observed. The solid yield of P-containing catalysts was higher than those of the P-free counterpart. The solid yields for $\mathrm{Co} / \gamma-\mathrm{Al}_{2} \mathrm{O}_{3}$ and $\mathrm{Fe} / \gamma-\mathrm{Al}_{2} \mathrm{O}_{3}$ were determined to be $15.21 \%$ and $14.39 \%$, respectively. On the other hand, they were decreased to $8.8 \%$ and $7.92 \%$ with an addition of phosphorus $\left(\mathrm{CoP} / \gamma-\mathrm{Al}_{2} \mathrm{O}_{3}\right.$ and $\left.\mathrm{Fe}_{2} \mathrm{P} / \gamma-\mathrm{Al}_{2} \mathrm{O}_{3}\right)$. This might be because the addition of phosphorus enhanced the acidity of catalyst, leading to the decrease of solid yield on active sites of catalysts. The HHVs of bio-oils through HDO were determined to be $34.41 \mathrm{MJ} / \mathrm{kg}\left(\mathrm{Co} / \gamma-\mathrm{Al}_{2} \mathrm{O}_{3}\right)$ and $34.28 \mathrm{MJ} / \mathrm{kg}$ $\left(\mathrm{Fe} / \gamma-\mathrm{Al}_{2} \mathrm{O}_{3}\right)$, while for phosphide catalysts in the range of $28.87-33.94 \mathrm{MJ} / \mathrm{kg}$. 
Table 3. Product distribution of Saccharina japonica bio-oil for different conditions in an autoclave reactor at reaction time of 60 min

\begin{tabular}{|c|c|c|c|c|c|c|c|c|c|c|}
\hline Reaction Con & litions & $\begin{array}{l}350{ }^{\circ} \mathrm{C} \\
3 \mathrm{Bar}\end{array}$ & $\begin{array}{l}350{ }^{\circ} \mathrm{C} \\
6 \mathrm{Bar}\end{array}$ & $\begin{array}{l}350^{\circ} \mathrm{C}, \\
15 \mathrm{Bar}\end{array}$ & $\begin{array}{c}350^{\circ} \mathrm{C}, \\
15 \mathrm{Bar}, \\
\text { HZSM-5 }\end{array}$ & $\begin{array}{c}350{ }^{\circ} \mathrm{C} \\
15 \mathrm{Bar} \\
\mathrm{Co} / \gamma-\mathrm{Al}_{2} \mathrm{O}_{3}\end{array}$ & $\begin{array}{c}350{ }^{\circ} \mathrm{C} \\
15 \mathrm{Bar} \\
\mathrm{Fe} / \gamma-\mathrm{Al}_{2} \mathrm{O}_{3}\end{array}$ & $\begin{array}{c}350{ }^{\circ} \mathrm{C}, \\
15 \mathrm{Bar}, \\
\mathrm{CoP} / \gamma-\mathrm{Al}_{2} \mathrm{O}_{3}\end{array}$ & $\begin{array}{c}350{ }^{\circ} \mathrm{C} \\
15 \mathrm{Bar}, \\
\mathrm{Fe}_{2} \mathrm{P} / \gamma-\mathrm{Al}_{2} \mathrm{O}_{3}\end{array}$ & $\begin{array}{c}350{ }^{\circ} \mathrm{C}, \\
15 \mathrm{Bar}, \\
\mathrm{CoMoP} / \gamma-\mathrm{Al}_{2} \mathrm{O}_{3}\end{array}$ \\
\hline \multirow{5}{*}{$\begin{array}{l}\text { Product Yield } \\
\text { (wt.\%) }\end{array}$} & Liquid & $77.24 \pm 0.21$ & $78.09 \pm 0.18$ & $80.17 \pm 0.08$ & $78.60 \pm 0.11$ & $74.28 \pm 0.20$ & $73.63 \pm 0.16$ & $75.14 \pm 0.11$ & $72.76 \pm 0.07$ & $68.58 \pm 0.16$ \\
\hline & Moisture & $19.87 \pm 0.08$ & $17.61 \pm 0.10$ & $11.52 \pm 0.05$ & $19.57 \pm 0.19$ & $22.39 \pm 0.22$ & $17.89 \pm 0.13$ & $17.33 \pm 0.09$ & $21.22 \pm 0.10$ & $31.97 \pm 0.25$ \\
\hline & Organic & $80.13 \pm 0.08$ & $82.39 \pm 0.10$ & $88.48 \pm 0.05$ & $80.43 \pm 0.19$ & $77.61 \pm 0.22$ & $82.11 \pm 0.13$ & $82.67 \pm 0.09$ & $78.78 \pm 0.10$ & $68.03 \pm 0.25$ \\
\hline & Solid & $13.93 \pm 0.28$ & $13.87 \pm 0.14$ & $13.29 \pm 0.15$ & $14.97 \pm 0.28$ & $10.51 \pm 0.37$ & $11.98 \pm 0.27$ & $16.06 \pm 0.18$ & $19.42 \pm 0.26$ & $25.23 \pm 0.40$ \\
\hline & Gas & $8.83 \pm 0.07$ & $8.04 \pm 0.31$ & $6.54 \pm 0.22$ & $6.43 \pm 0.17$ & $15.21 \pm 0.18$ & $14.39 \pm 0.42$ & $8.8 \pm 0.30$ & $7.82 \pm 0.20$ & $6.19 \pm 0.23$ \\
\hline \multirow{4}{*}{$\begin{array}{c}\text { Elemental } \\
\text { Analysis (wt.\%) }\end{array}$} & $\mathrm{C}$ & 72.44 & 71.46 & 72.60 & 73.16 & 73.39 & 73.42 & 70.16 & 63.83 & 72.48 \\
\hline & $\mathrm{H}$ & 8.46 & 8.39 & 8.59 & 8.38 & 8.54 & 8.42 & 8.43 & 8.22 & 8.58 \\
\hline & $\mathrm{N}$ & 3.21 & 3.27 & 3.37 & 3.19 & 3.44 & 3.62 & 3.07 & 2.97 & 3.03 \\
\hline & $\mathrm{O}$ & 15.89 & 16.88 & 15.44 & 15.26 & 14.63 & 14.54 & 18.34 & 24.98 & 15.91 \\
\hline HHV (MJ/kg) & & 33.74 & 33.09 & 33.99 & 33.99 & 34.41 & 34.28 & 32.51 & 28.87 & 33.94 \\
\hline \multirow{7}{*}{$\begin{array}{l}\text { Gas Selectivity } \\
(\mathrm{mol} \%)\end{array}$} & $\mathrm{CH}_{4}$ & 7.61 & 8.25 & 10.32 & 9.05 & 10.24 & 12.05 & 9.27 & 5.22 & 5.17 \\
\hline & $\mathrm{C}_{2} \mathrm{H}_{4}$ & 0.76 & 0.82 & 1.05 & 1.02 & 0.62 & 0.64 & 0.82 & 0.77 & 0.97 \\
\hline & $\mathrm{C}_{2} \mathrm{H}_{6}$ & 1.69 & 1.75 & 2.10 & 2.08 & 1.79 & 1.77 & 1.43 & 1.35 & 1.10 \\
\hline & $\mathrm{C}_{3} \mathrm{H}_{6}$ & 1.46 & 1.54 & 1.92 & 1.95 & 2.05 & 1.85 & 1.02 & 1.38 & 0.97 \\
\hline & $\mathrm{C}_{3} \mathrm{H}_{8}$ & 0.54 & 0.56 & 0.62 & 0.83 & 0.87 & 0.60 & 0.37 & 0.47 & 0.29 \\
\hline & $\mathrm{CO}$ & 0.18 & 0.49 & 1.67 & 0.83 & 0.72 & 0.90 & 1.36 & 0.17 & 1.83 \\
\hline & $\mathrm{CO}_{2}$ & 87.76 & 86.59 & 82.32 & 84.24 & 83.71 & 82.19 & 85.73 & 90.64 & 89.67 \\
\hline
\end{tabular}




\subsection{Compositions of Gas Product}

Table 3 also shows gaseous product distributions by non-catalytic and catalytic HDO of SJO. The gas compositions mostly consisted of $\mathrm{CO}, \mathrm{CO}_{2}, \mathrm{CH}_{4}$, and other hydrocarbon gases and varied depending on the reaction conditions. The $\mathrm{CH}_{4}$ was formed by cracking and hydrocracking of alkyl groups during the upgrading process. Without a catalyst, $\mathrm{CH}_{4}$ content in gas products increased from 7.61 to $10.32 \mathrm{~mol} \%$ with increasing pressure from 3 to 15 bar. This was probably due to the increase in the demethylation reaction rate. The demethylation was favored in $\mathrm{HDO}$ with $\mathrm{Co} / \gamma-\mathrm{Al}_{2} \mathrm{O}_{3}(10.24 \mathrm{~mol} \%)$ and $\mathrm{Fe} / \gamma-\mathrm{Al}_{2} \mathrm{O}_{3}(12.05 \mathrm{~mol} \%)$ catalysts. In this study, $\mathrm{CO}_{2}$ was identified as a major component among produced gases (82.19-90.64 mol\%), indicating that the organic compounds in raw SJO underwent decarboxylation [12]. For the HDO with catalysts, on the other hand, the decarboxylation reaction was more predominant than decarbonylation. Particularly for $\mathrm{Fe}_{2} \mathrm{P} / \gamma-\mathrm{Al}_{2} \mathrm{O}_{3}$ and $\mathrm{CoMoP} / \gamma-\mathrm{Al}_{2} \mathrm{O}_{3}$ catalysts, high selectivity to carbon dioxide was observed, which is likely to be attributed to promoted dehydration and decarboxylation by addition of phosphorus [21,22].

\subsection{Bio-Oil Analysis}

The atomic $\mathrm{C} / \mathrm{O}$ ratio of bio-oils obtained by HDO was calculated based on the result of the elemental analysis of the bio-oil. By performing catalytic $\mathrm{HDO}$, the $\mathrm{C} / \mathrm{O}$ ratio of bio-oil increased from 4.12 (without catalyst) to $4.75(\mathrm{HZSM}-5), 6.34\left(\mathrm{Co} / \gamma-\mathrm{Al}_{2} \mathrm{O}_{3}\right), 5.67\left(\mathrm{Fe} / \gamma-\mathrm{Al}_{2} \mathrm{O}_{3}\right)$, and $6.75\left(\mathrm{CoMoP} / \gamma-\mathrm{Al}_{2} \mathrm{O}_{3}\right)$, while decreasing to 3.77 and 3.71 for $\mathrm{CoP} / \mathrm{Al}_{2} \mathrm{O}_{3}$ and $\mathrm{Fe}_{2} \mathrm{P} / \gamma-\mathrm{Al}_{2} \mathrm{O}_{3}$, respectively. The decrease in $\mathrm{O}$ content after $\mathrm{HDO}$ reaction was due to the removal of oxygenates from the gas $\left(\mathrm{CO}, \mathrm{CO}_{2}\right)$ or $\mathrm{H}_{2} \mathrm{O}$ via deoxygenation and dehydration reactions. The carbon and oxygen balances of the reactant and products were shown in Table 4.

Table 4. Carbon and oxygen balance of the reactant and product during HDO reaction.

\begin{tabular}{|c|c|c|c|c|c|c|c|c|c|c|}
\hline \multicolumn{2}{|c|}{$\begin{array}{l}\text { Reaction } \\
\text { Conditions }\end{array}$} & \multirow{2}{*}{$\begin{array}{c}350{ }^{\circ} \mathrm{C}, \\
3 \text { Bar } \\
0.31\end{array}$} & \multirow{2}{*}{$\begin{array}{c}350^{\circ} \mathrm{C}, \\
6 \mathrm{Bar} \\
0.27\end{array}$} & \multirow{2}{*}{$\begin{array}{c}350{ }^{\circ} \mathrm{C}, \\
15 \mathrm{Bar} \\
0.23\end{array}$} & \multirow{2}{*}{$\begin{array}{c}\begin{array}{c}350^{\circ} \mathrm{C}, \\
15 \text { Bar, }\end{array} \\
\text { HZSM-5 }\end{array}$} & \multirow{2}{*}{$\begin{array}{c}350{ }^{\circ} \mathrm{C}, \\
15 \mathrm{Bar}, \\
\mathrm{Co} / \gamma-\mathrm{Al}_{2} \mathrm{O}_{3} \\
0.64\end{array}$} & \multirow{2}{*}{$\begin{array}{c}350{ }^{\circ} \mathrm{C}, \\
15 \mathrm{Bar}_{,} \\
\mathrm{Fe} / \gamma-\mathrm{Al}_{2} \mathrm{O}_{3} \\
0.88\end{array}$} & \multirow{2}{*}{$\begin{array}{c}350{ }^{\circ} \mathrm{C}, \\
15 \mathrm{Bar}, \\
\mathrm{CoP} / \gamma-\mathrm{Al}_{2} \mathrm{O}_{3} \\
0.3\end{array}$} & \multirow{2}{*}{$\begin{array}{c}350{ }^{\circ} \mathrm{C}, \\
15 \mathrm{Bar}, \\
\mathrm{Fe}_{2} \mathrm{P} / \gamma-\mathrm{Al}_{2} \mathrm{O}_{3} \\
0.4\end{array}$} & \multirow{2}{*}{$\begin{array}{c}350{ }^{\circ} \mathrm{C}, \\
15 \mathrm{Bar}, \\
\mathrm{CoMoP} / \gamma-\mathrm{Al}_{2} \mathrm{O}_{3} \\
0.21\end{array}$} \\
\hline Gas & $\mathrm{C}$ & & & & & & & & & \\
\hline Char & C & 1.344 & 1.261 & 1.115 & 1.261 & 1.053 & 1.011 & 1.471 & 1.86 & 2.013 \\
\hline Product (g) & $\mathrm{O}$ & 0.06 & 0.09 & 0.49 & 0.16 & 0.11 & 0.09 & 0.1 & 0.08 & 0.06 \\
\hline Organic & $\mathrm{C}$ & 4.43 & 4.55 & 4.74 & 4.60 & 4.39 & 4.19 & 4.31 & 3.82 & 3.86 \\
\hline Phase (g) & $\mathrm{O}$ & 0.95 & 1.09 & 1.15 & 0.97 & 0.69 & 0.74 & 1.14 & 1.03 & 0.57 \\
\hline C/O Ratio & & 4.68 & 4.18 & 4.12 & 4.75 & 6.34 & 5.67 & 3.77 & 3.71 & 6.75 \\
\hline
\end{tabular}

The pyrolysis bio-oil is known as a complex mixture consisting of hundreds of components with a wide range of molecular weight. Table 5 shows the GC-MS analysis data of the bio-oils produced by $\mathrm{HDO}$ reaction at $15 \mathrm{bar}$ and $350^{\circ} \mathrm{C}$ with/without catalysts (based on peak area \%). The bio-oil mainly contained components such as fatty acids, dianhydromannitol, isosorbide, 2-furyl methyl ketone (2-FMK), and derivatives of ketones. It can be observed that HZSM-5 was effective in the conversion of dianhydromannitol and isosorbide and the production of aromatic compounds such as derivatives of pyrazine, pyridinamine, and indole. This result was in good agreement with other literature [12]. An increase in the alkane selectivity, resulting in a decrease in the selectivity to fatty acids, might be explained by decarboxylation of fatty acids by catalytic activity of metal catalysts $\left(\mathrm{Fe} / \mathrm{Al}_{2} \mathrm{O}_{3}\right.$ and $\mathrm{Fe}_{2} \mathrm{P} / \mathrm{Al}_{2} \mathrm{O}_{3}$ ) [23]. As shown in Table 4, the selectivity of ketone derivatives in the produced bio-oils after HDO, especially 2-FMK, was found to be lower than that of raw SJO. This result was also in good agreement with our previous study on HDO of bio-oil model compounds [14-16]. 
Table 5. Compounds identified by gas chromatograph/mass spectrometry (GC-MS) of bio-oil produced from HDO of Saccharina japonica bio-oil in an autoclave at $350{ }^{\circ} \mathrm{C}$ under pressure of 15 bar using various catalysts (results are based on peak area \%).

\begin{tabular}{|c|c|c|c|c|c|c|c|c|c|}
\hline \multirow{2}{*}{ Composition of Bio-Oil } & \multirow{2}{*}{$\begin{array}{c}\text { Bio-Oil at } 4500^{\circ} \mathrm{C} \\
\quad 4.0 \times \mathrm{U}_{\mathrm{mf}}\end{array}$} & \multirow{2}{*}{$\begin{array}{c}\text { w/o } \\
\text { Catalyst }\end{array}$} & \multicolumn{6}{|c|}{ Catalysts } & \multirow{2}{*}{ Structure } \\
\hline & & & HZSM-5 & $\mathrm{Co} / \gamma-\mathrm{Al}_{2} \mathrm{O}_{3}$ & $\mathrm{CoP} / \gamma-\mathrm{Al}_{2} \mathrm{O}_{3}$ & $\mathrm{CoMoP} / \gamma-\mathrm{Al}_{2} \mathrm{O}_{3}$ & $\mathrm{Fe} / \gamma-\mathrm{Al}_{2} \mathrm{O}_{3}$ & $\mathrm{Fe}_{2} \mathrm{P} / \gamma-\mathrm{Al}_{2} \mathrm{O}_{3}$ & \\
\hline 2-methyl-2-cyclopenten-1-one & 1.84 & 0.41 & 0.49 & 0.61 & & 2.14 & 2.41 & 2.44 & \\
\hline 3-methyl-Butanal & & & & & 3.53 & & 3.66 & & \\
\hline 2-Furyl methyl ketone & 12.7 & 6.53 & 5.62 & 2.45 & 5.22 & 7.7 & 4.36 & 6.11 & \\
\hline 3,4-dimethyl-2-cyclopentenone & & & 1.64 & & & & & 1.32 & \\
\hline 2-hydroxy-3,4-dimethyl-2-Cyclopenten-1-one & 2.33 & 2.75 & & & & & & & \\
\hline 2-Hydroxy-3-ethyl-2-Cyclopenten-1-one & 1.25 & 1.82 & & & & & & & \\
\hline 2,3,6-Trimethylpyrazine & & & 3.47 & & & & & & \\
\hline 2,3-dimethyl-2-cyclopenten-1-one & 3.29 & 1.93 & 2.93 & 1.05 & 2.04 & 1.59 & 2.18 & 2.02 & \\
\hline 2,3,4-trimethyl-2-cyclopenten-1-one & 2.29 & 2.05 & 1.21 & 0.9 & 2.71 & & 2.26 & 2.15 & \\
\hline 3-ethyl-2,5-dimethyl-Pyrazine & 4.23 & 1.76 & 0.67 & & & & & & \\
\hline 2-methoxy-Phenol & & & & 0.26 & & 3.14 & 0.77 & & \\
\hline 2,4-Dimethyl phenol & 1.01 & 0.98 & & & & & 1.09 & 1.23 & \\
\hline
\end{tabular}


Table 5. Cont

\begin{tabular}{|c|c|c|c|c|c|c|c|c|c|}
\hline \multirow{2}{*}{ Composition of Bio-Oil } & \multirow{2}{*}{$\begin{array}{c}\text { Bio-Oil at } 450^{\circ} \mathrm{C} \\
4.0 \times \mathrm{U}_{\mathrm{mf}}\end{array}$} & \multirow{2}{*}{$\begin{array}{c}\text { w/o } \\
\text { Catalyst }\end{array}$} & \multicolumn{6}{|c|}{ Catalysts } & \multirow{2}{*}{ Structure } \\
\hline & & & HZSM-5 & $\mathrm{Co} / \gamma-\mathrm{Al}_{2} \mathrm{O}_{3}$ & $\mathrm{CoP} / \gamma-\mathrm{Al}_{2} \mathrm{O}_{3}$ & $\mathrm{CoMoP} / \gamma-\mathrm{Al}_{2} \mathrm{O}_{3}$ & $\mathrm{Fe} / \gamma-\mathrm{Al}_{2} \mathrm{O}_{3}$ & $\mathrm{Fe}_{2} \mathrm{P} / \gamma-\mathrm{Al}_{2} \mathrm{O}_{3}$ & \\
\hline 2,3-Dimethyl-5-ethyl-Pyrazine & 1.95 & 1.89 & 1.76 & & & & & & \\
\hline 1-Acetyl-1-cyclohexene & & & 2.61 & & & & & & \\
\hline 4-Ethyl-2,5,6-Trimethylpyrimidine & & & 2.42 & & & & & & \\
\hline Isosorbide & 3.48 & 2.66 & & 4.03 & 11.91 & 6.96 & 6.12 & 18.52 & \\
\hline Dianhydromannitol & 22.26 & 20.73 & 3.35 & 17.33 & 19.67 & 23.82 & 20.68 & 20.64 & \\
\hline 3-ethoxy-2-Pyridinamine & & & 2.57 & & & & & & \\
\hline 1,2-dimethoxy-Benzene & & & 1.23 & & & & & & \\
\hline 6,7-dihydro-2,5-dimethyl-5H-cyclopentapyrazine & & & 2.63 & & & & & & \\
\hline Tetradecane & & & 1.87 & 1.97 & & 1.18 & 2.5 & & $\mathrm{C}_{14} \mathrm{H}_{30}$ \\
\hline n-Pentadecane & & & 1.42 & 0.7 & & 1.04 & & & $\mathrm{C}_{15} \mathrm{H}_{32}$ \\
\hline n-Hexadecane & & & & & & 2.61 & 0.71 & & \\
\hline 2-Ethylhexyl 2-ethylhexanoate & & & & & & 2.83 & & & \\
\hline Methyl n-tetradecanoate & & & 1.09 & 1.78 & 2.49 & 1.78 & 1.97 & 1.02 & \\
\hline Tetradecanoic acid & & & 1.29 & & 2.04 & & & & \\
\hline 4-Benzylaniline & & & & & & 6.35 & & & \\
\hline 1,1-Diphenylhydrazine & & & & & & 2.65 & & & \\
\hline
\end{tabular}


Table 5. Cont.

\begin{tabular}{|c|c|c|c|c|c|c|c|c|c|}
\hline \multirow{2}{*}{ Composition of Bio-Oil } & \multirow{2}{*}{$\begin{array}{c}\text { Bio-Oil at } 450^{\circ} \mathrm{C} \\
\quad 4.0 \times \mathrm{U}_{\mathrm{mf}}\end{array}$} & \multirow{2}{*}{$\begin{array}{c}\text { w/o } \\
\text { Catalyst }\end{array}$} & \multicolumn{6}{|c|}{ Catalysts } & \multirow{2}{*}{ Structure } \\
\hline & & & HZSM-5 & $\mathrm{Co} / \gamma-\mathrm{Al}_{2} \mathrm{O}_{3}$ & $\mathrm{CoP} / \gamma-\mathrm{Al}_{2} \mathrm{O}_{3}$ & $\mathrm{CoMoP} / \gamma-\mathrm{Al}_{2} \mathrm{O}_{3}$ & $\mathrm{Fe} / \gamma-\mathrm{Al}_{2} \mathrm{O}_{3}$ & $\mathrm{Fe}_{2} \mathrm{P} / \gamma-\mathrm{Al}_{2} \mathrm{O}_{3}$ & \\
\hline 3,7,11,15-tetramethyl-2-Hexadecene & 1.2 & 2.49 & 4.99 & 1.65 & & & 2.72 & & \\
\hline Methyl hexadecanoate & 0.46 & 0.87 & 1.28 & 1.44 & 3.42 & 2.3 & 2.64 & 1.21 & \\
\hline Hexadecanoic acid & 5.16 & 3.44 & 1.47 & 1.91 & 2.23 & 1.09 & & & \\
\hline 9-Octadecenoic acid & 4.65 & 3.41 & & & & & & & \\
\hline Methyl-9-octadecenoate & & 1.67 & 0.67 & 2.19 & 3.35 & 1.09 & 2.96 & & \\
\hline 1-Methyl-2-phenyl-1H-indole & & & 6.55 & & & & & & \\
\hline 3-Nitrophthalic acid & & & & 37.4 & & & & & \\
\hline
\end{tabular}


The simulated distillation using TGA, which is based on the boiling point of a carbonaceous liquid, has been conducted for the SJ bio-oil [3,12]. As shown in Figure 3, the carbon number distribution of bio-oil could be classified into three groups such as $C_{5}-C_{11}, C_{12}-C_{18}$, and $C_{20}-C_{38}$, corresponding to gasoline, kerosene-diesel, and heavy oil fractions, respectively. The distribution of these fractions in the SJO (without catalyst) was $36.24\left(C_{5}-C_{11}\right), 36.17\left(C_{12}-C_{18}\right)$, and $27.38 \mathrm{wt} . \%\left(C_{20}-C_{38}\right)$, respectively. However, there were significant changes in the carbon number distribution for the bio-oils by catalytic HDO. The fractions of $\mathrm{C}_{5}-\mathrm{C}_{11}, \mathrm{C}_{12}-\mathrm{C}_{18}$, and $\mathrm{C}_{20}-\mathrm{C}_{38}$ for bio-oil (organic phase) upgraded by HDO were in the range of $30.7-44.81,38.62-48.92$, and $14.16-28.64 \mathrm{wt} . \%$, respectively.

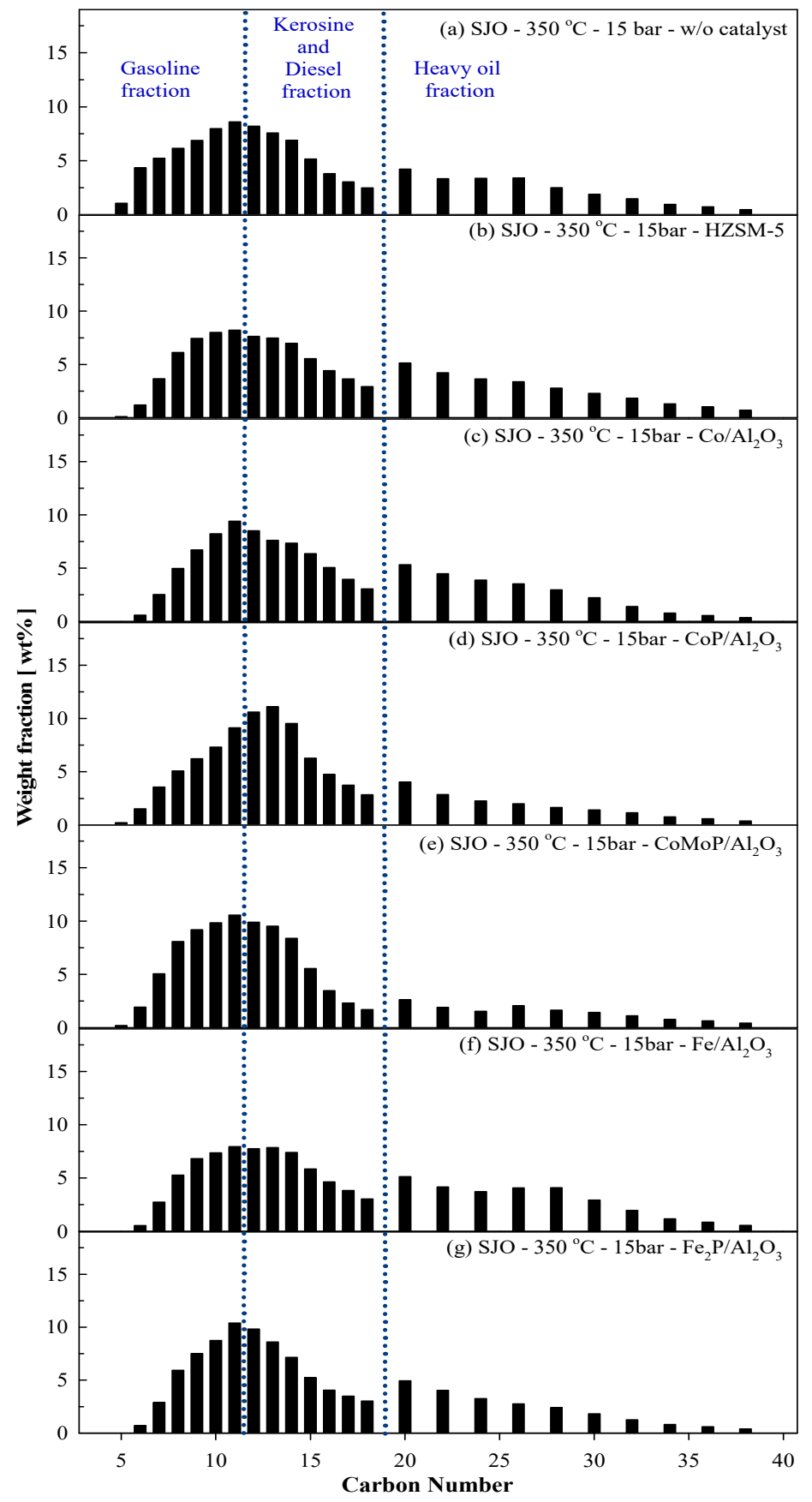

Figure 3. Carbon number distribution of bio-oil produced from HDO of Saccharina japonica bio-oil in an autoclave at $350{ }^{\circ} \mathrm{C}$ under pressure of 15 bar using different catalysts. 


\section{Material and Methods}

\subsection{Sample and Catalysts Preparation}

The SJ biomass used in this study was provided by the Cleaner Production Institute of Pukyong National University. The samples were subjected to drying at $105^{\circ} \mathrm{C}$ overnight to achieve equilibrium moisture before the experiments. The bio-oils (organic phase) were obtained by fast pyrolysis at $450{ }^{\circ} \mathrm{C}$ and the HDO was proceeded at the fluidization velocity of $4.0 \times \mathrm{U}_{\mathrm{mf}}$.

Following the ASTM standard method (ASTM E 1756-1 and ASTM E 1755-01), the ultimate and proximate analyses of biomass samples and bio-oil were conducted. The thermal decomposition of the bio-oil was analyzed using thermogravimetric analyzer (TGA N-1000, SINCO) under a nitrogen flow rate of $20 \mathrm{~mL} / \mathrm{min}$, from room temperature up to $700^{\circ} \mathrm{C}$ at a heating rate $10^{\circ} \mathrm{C} / \mathrm{min}$.

All catalysts tested in this study were ground and sieved to 80-100 mesh $(150-180 \mu \mathrm{m})$. The commercial HZSM- 5 catalyst was provided by Hyundai Petroleum Chem. Co. (South Korea) and was calcined at $550{ }^{\circ} \mathrm{C}$ for $5 \mathrm{~h}$ before use [24-28]. Alumina-supported monometallic $\left(\mathrm{Co} / \gamma-\mathrm{Al}_{2} \mathrm{O}_{3}\right.$ and $\left.\mathrm{Fe} / \gamma-\mathrm{Al}_{2} \mathrm{O}_{3}\right)$ and metal phosphorus $\left(\mathrm{Co} / \gamma-\mathrm{Al}_{2} \mathrm{O}_{3}\right.$ and $\left.\mathrm{Fe} / \gamma-\mathrm{Al}_{2} \mathrm{O}_{3}\right)$ catalysts were synthesized by impregnation method with $10 \mathrm{wt} . \%$ metal loading and a molar ratio of phosphorus (P) to metal (M) 1:1. Before the catalysts were used in the HDO process, they were calcined at $600{ }^{\circ} \mathrm{C}$ for $3 \mathrm{~h}$ and were further treated in the $\mathrm{H}_{2}$ environment at atmospheric pressure to reduce metal oxides or metal/metal-oxide phosphate to metal or metal phosphide, respectively. More details on catalysts preparation procedure and characterization methods are described in our prior work [15,16]. The specific surface area of the catalyst was determined using the multipoint Brunauer-Emmett-Teller (BET). Powder X-ray diffraction (XRD, MAC-18XHF, Rigaku, Japan) was also employed to understand the crystallographic structure of the catalysts.

\subsection{Experimental Setup and Analytical Method}

Upgrading of Saccharina japonica bio-oil (SJO) was carried out in an autoclave reactor. As shown in Figure 4, the system consists of a salt bath, a temperature controller, a mechanical stirrer, and a reactor with an inner volume of $100 \mathrm{~mL}$. A molten salt mixture as heat transfer fluid was prepared from a eutectic salt of $\mathrm{KNO}_{3}(59 \mathrm{wt} . \%)$ and $\mathrm{Ca}\left(\mathrm{NO}_{3}\right)_{2}(41 \mathrm{wt} . \%)$ [6,10]. The experiments were conducted at a fixed temperature of $350{ }^{\circ} \mathrm{C}$ under different initial pressures from 3 to 15 bar using hydrogen. With the autoclave submerged in the molten salt bath, a ratio of catalyst to bio-oil of 1:10 (i.e., $1 \mathrm{~g}$ of catalyst with $10 \mathrm{~g}$ bio-oil sample) was used in the catalytic experiments. The residence time of the reactant in the salt bath was $60 \mathrm{~min}$ for each condition. After each run, the reactor was removed from the bath and cooled to room temperature.

The samples after HDO were collected to calculate product yields by determining the ratio of mass of the product to that of the biomass fed to the system. The gas yield was determined by measuring the difference in the weight of the reactor before and after the reaction. To calculate the solid and liquid yields, liquid and solid products were first separated by solvent extraction with acetone using a micro filter paper (pore size: $0.45 \mu \mathrm{m}$ ). Then, the solid yield was calculated by weighing the solid and filter after drying, while the liquid yield was given by difference. For all the calculations presented, each data point was an average of more than two experiments.

The elemental compositions of the upgraded bio-oils were characterized by Flash EA1112, CE Instrument $[3,9,10]$. The moisture content was measured by a Karl-Fischer (CA-200, Mitsubishi, Seoul, South Korea). The gas compositions were identified by the gas chromatography (YL 6500GC) equipped with dual detectors, a flame ionization detector (FID) using Porapak N column to identify hydrocarbon gases $\left(\mathrm{C}_{1}-\mathrm{C}_{4}\right)$ and a thermal conductivity detector (TCD) using a Molecular sieve 13X column for $\mathrm{H}_{2}, \mathrm{CO}, \mathrm{CO}_{2}$, and $\mathrm{CH}_{4}$. The FID was operated at $250{ }^{\circ} \mathrm{C}$, using high-purity nitrogen $(99.999 \%)$ as a carrier gas with flow rate $20 \mathrm{~mL} / \mathrm{min}$, while the TCD detector was held constant at $150^{\circ} \mathrm{C}$ with a constant flow rate $(20 \mathrm{~mL} / \mathrm{min})$ of argon $(99.999 \%$ purity) as a carrier gas. Using helium carrier gas with a constant flow rate of $1.0 \mathrm{~mL} / \mathrm{min}$, a gas chromatograph/mass spectrometry (GC/MS, 7890A/5975C, 
Agilent, Seoul, South Korea) with a capillary column of HP-5MS (30 m $\times 0.25 \mathrm{~mm} \times 0.25 \mu \mathrm{m})$ was applied to identify the compositions of bio-oils [3,5]. Starting at $40^{\circ} \mathrm{C}$, with a heating rate of $10^{\circ} \mathrm{C}$ $/ \mathrm{min}$, the oven temperature increased to $280^{\circ} \mathrm{C}$ and was maintained for $10 \mathrm{~min}$. The temperature of injector was set constant at $280^{\circ} \mathrm{C}$ and injection volume was $1 \mu \mathrm{L}$.

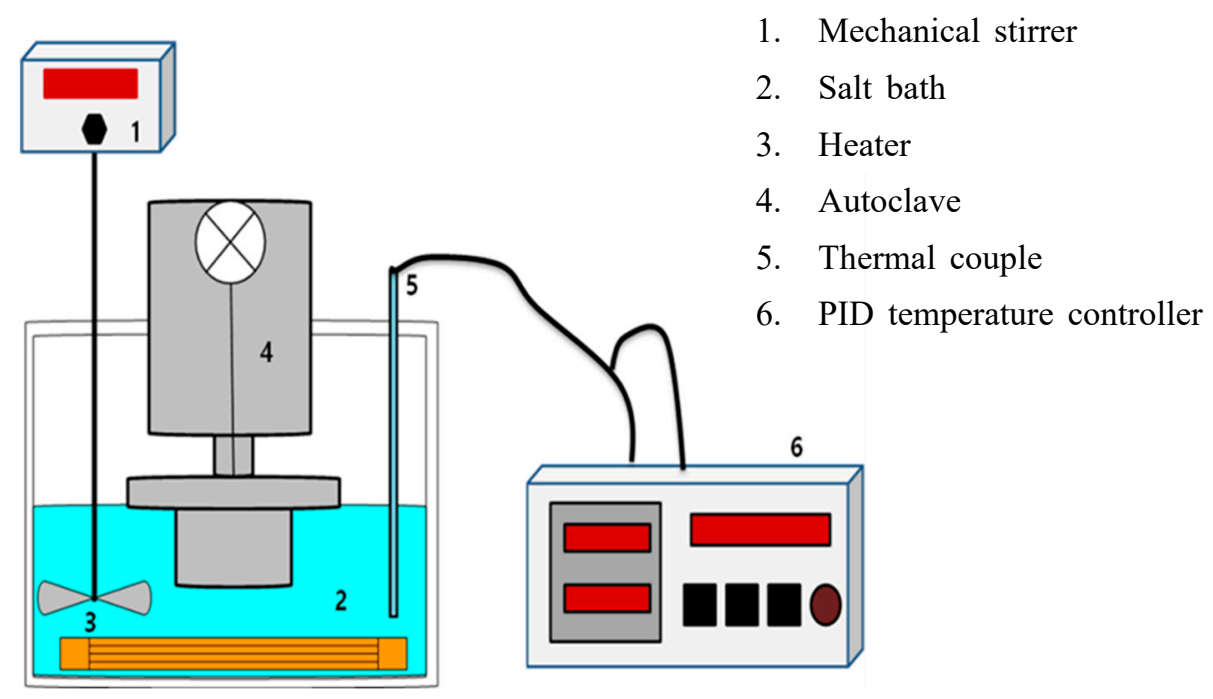

Figure 4. Schematic diagram of experimental apparatus for hydrodeoxygenation (HDO) of Saccharina japonica bio-oil.

\section{Conclusions}

The HDO process of Saccharina japonica bio-oil was systematically investigated in an autoclave reactor. The HHVs of bio-oils upgraded by HDO were in the range of 33.74-33.99 MJ/kg in the absence of a catalyst. Although the liquid yield decreased, however, the quality of bio-oil increased by using metal catalysts in HDO of Saccharina japonica bio-oil. The HHVs of HDO bio-oils were increased to $34.41 \mathrm{MJ} / \mathrm{kg}$ by using $\mathrm{Co} / \gamma-\mathrm{Al}_{2} \mathrm{O}_{3}$ catalyst but decreased with metal phosphide catalysts. The $\mathrm{C} / \mathrm{O}$ ratio of $\mathrm{HDO}$ bio-oil with $\mathrm{CoMoP} / \gamma-\mathrm{Al}_{2} \mathrm{O}_{3}, \mathrm{Co} / \gamma-\mathrm{Al}_{2} \mathrm{O}_{3}, \mathrm{Fe} / \gamma-\mathrm{Al}_{2} \mathrm{O}_{3}$, and HZSM- 5 were higher than that of raw Saccharina japonica bio-oil and $\mathrm{HDO}$ bio-oil with $\mathrm{CoP} / \gamma-\mathrm{Al}_{2} \mathrm{O}_{3}$ or $\mathrm{Fe} 2 \mathrm{P} / \gamma-\mathrm{Al}_{2} \mathrm{O}_{3}$ catalyst. Metal phosphide catalysts were likely to promote the decarboxylation, while metal catalyst elevating the demethylation reactions. The carbon number distribution of bio-oil was mainly distributed in the range $C_{5}-C_{11}$ and $C_{12}-C_{18}$ fractions. Our results revealed the feasibility of upgrading SJO to high-quality bio-oil using catalysts, and this upgraded bio-oil could be further used as a great source for manufacturing alternative bio-fuels and/or valuable chemicals.

Author Contributions: Conceptualization, H.V.L., S.-S.K. and J.K.; methodology, H.V.L. and S.-S.K.; formal analysis and investigation, H.V.L., J.H.C. and S.-S.K.; resources, J.H.C. and H.C.W.; writing-original draft preparation, H.V.L. and S.-S.K.; writing-review and editing, H.V.L., S.-S.K., H.T.H. and J.K.; supervision, S.-S.K. and J.K.; project administration, H.C.W. and S.-S.K.

Funding: This research received no external funding.

Acknowledgments: This research was supported by the Basic Science Research Program through the National Research Foundation of Korea (NRF), funded by the Ministry of Education, Science and Technology (NRF-2017R1E1A1A01074282).

Conflicts of Interest: The authors declare no conflict of interest.

\section{References}

1. Zhang, S.; Dong, Q.; Zhang, L.; Xiong, Y. Effects of water washing and torrefaction on the pyrolysis behavior and kinetics of rice husk through TGA and Py-GC/MS. Bioresour. Technol. 2016, 199, 352-361. [CrossRef] [PubMed] 
2. Kim, S.-S.; Shenoy, A.; Agblevor, F. Themogravimetric and kinetic study of Pinyon pine in the various gases. Bioresour. Technol. 2014, 156, 297-302. [CrossRef] [PubMed]

3. Ly, H.V.; Limm, D.-H.; Simm, J.W.; Kim, S.-S.; Kim, J. Catalytic pyrolysis of tulip tree (Liriodendron) in bubbling fluidized-bed reactor for upgrading bio-oil using dolomite catalyst. Energy 2018, 162, 564-575. [CrossRef]

4. Honus, S.; Kumagai, S.; Molnar, V.; Fedorko, G.; Yoshioka, T. Pyrolysis gases produced from individual and mixed PE, PP, PS, PVC, and PET-Part II: Fuel characteristics. Fuel 2018, 221, 361-373. [CrossRef]

5. Ly, H.V.; Kim, S.-S.; Woo, H.C.; Choi, J.H.; Suh, D.J.; Kim, J. Fast pyrolysis of macroalga Saccharina japonica in a bubbling fluidized-bed reactor for bio-oil production. Energy 2015, 93, 1436-1446. [CrossRef]

6. Ly, H.V.; Kim, S.-S.; Kim, J.; Choi, J.H.; Woo, H.C. Effect of acid washing on pyrolysis of Cladophora socialis alga in microtubing reactor. Energy Convers. Manag. 2015, 106, 260-267. [CrossRef]

7. Supaporn, P.; Ly, H.V.; Kim, S.-S.; Yeom, S.H. Bio-oil production using residual sewage sludge after lipid and carbohydrate extraction. Environ. Eng. Res. 2019, 24, 202-210. [CrossRef]

8. Guedes, R.E.; Luna, A.S.; Torres, A.R. Operating parameters for bio-oil production in biomass pyrolysis: A review. J. Anal. Appl. Pyrol. 2018, 129, 134-149. [CrossRef]

9. Kim, S.-S.; Ly, H.V.; Choi, J.H.; Kim, J.; Woo, H.C. Pyrolysis characteristics and kinetics of the alga Saccharina japonica. Bioresour. Technol. 2012, 123, 445-451. [CrossRef]

10. Kim, S.-S.; Ly, H.V.; Kim, J.; Choi, J.H.; Woo, H.C. Thermogravimetric characteristics and pyrolysis kinetics of Alga Sagarssum sp. biomass. Bioresour. Technol. 2013, 139, 242-248. [CrossRef]

11. Cao, B.; Wang, S.; Hu, Y.; Abomohra, A.E.-F.; Qian, L.; He, Z.; Wang, Q.; Uzoejinwa, B.B.; Esakkimuthu, S. Effect of washing with diluted acids on Enteromorpha clathrata pyrolysis products: Towards enhanced bio-oil from seaweeds. Renew. Energy 2019, 138, 29-38. [CrossRef]

12. Ly, H.V.; Choi, J.H.; Woo, H.C.; Kim, S.-S.; Kim, J. Upgrading bio-oil by catalytic fast pyrolysis of acid-washed Saccharina japonica alga in a fluidized-bed reactor. Renew. Energy 2019, 133, 11-22. [CrossRef]

13. Lorenzetti, C.; Conti, R.; Fabbri, D.; Yanik, J. A comparative study on the catalytic effect of H-ZSM5 on upgrading of pyrolysis vapors derived from lignocellulosic and proteinaceous biomass. Fuel 2016, 166, 446-452. [CrossRef]

14. Ly, H.V.; Im, K.; Go, Y.; Galiwango, E.; Kim, S.-S.; Kim, J.; Choi, J.H.; Woo, H.C. Spray pyrolysis synthesis of $\gamma-\mathrm{Al}_{2} \mathrm{O}_{3}$ supported metal and metal phosphide catalysts and their activity in the hydrodeoxygenation of a bio-oil model compound. Energy Convers. Manag. 2016, 127, 545-553. [CrossRef]

15. Le, T.A.; Ly, H.V.; Kim, J.; Kim, S.-S.; Choi, J.H.; Woo, H.C.; Othman, M.R. Hydrodeoxygenation of 2-furyl methyl ketone as a model conpound in bio-oil from pyrolysis of Saccharaina japonica alga in fixe-bed reactor. Chem. Eng. J. 2014, 105, 157-163. [CrossRef]

16. Ly, H.V.; Galiwango, E.; Kim, S.-S.; Kim, J.; Choi, J.H.; Woo, H.C.; Othman, M.R. Hydrodeoxygenation of 2-furyl methyl ketone as a model compound of algal Saccharina Japonica bio-oil using iron phosphide catalyst. Chem. Eng. J. 2017, 317, 302-308. [CrossRef]

17. Cheng, S.; Wei, L.; Zhao, X.; Julson, J. Application, deactivation, and regeneration of heterogeneous catalysts in bio-oil upgrading. Catalysts 2016, 6, 195. [CrossRef]

18. Cheng, S.; Wei, L.; Julson, J.; Rabnawaz, M. Upgrading pyrolysis bio-oil through hydrodeoxygenation (HDO) using non-sulfided Fe-Co/SiO 2 catalyst. Energy Convers. Manag. 2017, 150, 331-342. [CrossRef]

19. Sun, J.; Liu, N.; Zhai, S.; Xiao, Z.; An, Q.; Huan, D. Gold-titania/protonated zeolite nanocomposite photocatalysts for methyl orange degradation under ultraviolet and visible irradiation. Mater. Sci. Semicond. Process. 2014, 25, 286-293. [CrossRef]

20. Kim, S.-S.; Chun, B.H.; Kim, S.H. Non-isothermal pyrolysis of waste automobile lubricating oil in a stirred batch reactor. Chem. Eng. J. 2003, 93, 225-231. [CrossRef]

21. Zepeda, T.A.; Infantes-Molina, A.; Diaz de Leon, J.N.; Fuentes, S.; Alonso-Nunez, G.; Torres-Otanez, G.; Pawelec, B. Hydrodesulfurization enhancement of heavy and light S-hydrocarbons on NiMo/HMS catalysts modified with Al and P. Appl. Catal. A Gen. 2014, 484, 108-121. [CrossRef]

22. Prieur, B.; Meub, M.; Wittemann, M.; Klein, R.; Bellayer, S.; Fontaine, G. Phosphorylation of lignin: Characterization and investigation of the thermal decomposition. RSC Adv. 2017, 7, 16866-16877. [CrossRef]

23. Ngo, T.-A.; Kim, J.; Kim, S.-S. Fast pyrolysis of spent coffee waste and oak wood chips in a micro-tubular reactor. Energy Source Part A 2015, 37, 1186-1194. [CrossRef] 
24. Yathavan, B.K.; Agblevor, F.A. Catalytic pyrolysis of Pinyon-Juniper using red mud and HZSM-5. Energy Fuels 2013, 27, 6858-6865. [CrossRef]

25. Suchithra, T.-G.; Adhikari, S.; Chattanathan, S.A.; Gupta, R.B. Catalytic pyrolysis of green algae for hydrocarbon production using H+ZSM-5 catalyst. Bioresour. Technol. 2012, 118, 150-157. [CrossRef]

26. Lee, H.; Kim, Y.M.; Lee, I.G.; Jeon, J.K.; Jung, S.C.; Chung, J.D.; Choi, W.G.; Park, Y.K. Recent advances in the catalytic hydrodeoxygenation of bio-oil. Korean J. Chem. Eng. 2016, 33, 3299-3315. [CrossRef]

27. Lee, Y.J.; Shafaghat, H.; Kim, J.K.; Jeon, J.K.; Jung, S.C.; Lee, I.G.; Park, Y.K. Upgrading of pyrolysis bio-oil using $\mathrm{WO}_{3} / \mathrm{ZrO}_{2}$ and Amberlyst catalysts: Evaluation of acid number and viscosity. Korean J. Chem. Eng. 2017, 34, 2180-2187. [CrossRef]

28. Kim, H.N.; Shafaghat, H.; Kim, J.K.; Kang, B.S.; Jeon, J.K.; Jung, S.C.; Lee, I.G.; Park, Y.K. Stabilization of bio-oil over a low cost dolomite catalyst. Korean J. Chem. Eng. 2018, 35, 922-925. [CrossRef]

(C) 2019 by the authors. Licensee MDPI, Basel, Switzerland. This article is an open access article distributed under the terms and conditions of the Creative Commons Attribution (CC BY) license (http://creativecommons.org/licenses/by/4.0/). 